UDC 614.8.026.1

DOI: $10.21668 /$ health.risk/2020.4.15.eng

Research article

\title{
FACTORS THAT CAUSE CONTAGION AND SPREAD OF HIV AMONG PEOPLE FROM SOCIAL RISK GROUPS
}

\author{
S.O. Golodnova ${ }^{1}$, I.V. Fel'dblyum ${ }^{1}$, L.V. Yurkova ${ }^{2}$, E.V. Sarmometov ${ }^{3}$, V.V. Nikolenko ${ }^{1}$ \\ ${ }^{1}$ E.A. Wagner's Perm State Medical University, 26 Petropavlovskaya Str., Perm, 614000, Russian Federation \\ ${ }^{2}$ Perm Regional Ministry of Territorial Security, 14 Kuibysheva Str., Perm, 614006, Russian Federation \\ ${ }^{3}$ Perm Regional Center for the Prevention and Control over AIDS and Infectious Diseases, 21 Arkhitektora \\ Sviyazeva Str., Perm, 614088, Russian Federation
}

Despite all significant efforts being made by the public healthcare, state authorities, and public organizations, HIVinfection has been a topical issue over the last 30 years. Commercial sex workers (CSW) are a basic risk group when it comes down to this infection.

Our research goal was to determine HIV prevalence among commercial sex workers and risk factors that cause their contagion with it.

We performed an epidemiologic analytical ecologic examination to study HIV prevalence risk factors that cause spread of this infection among CSW. 154 CSW were questioned with a sociological procedure applied to do it; they lived in three cities in Perm region, and morbidity with HIV was higher than on average in the region in two of them, B. and $K$. The city $P$. was taken as a reference territory due to a relatively favorable situation with HIV infection spread there. Risk factors that caused HIV infection were determined via an observational analytical case-control study; the "case» group was made up of 46 CSW who were infected with HIV and the control group included 108 CSW who didn't have this infection. All the obtained data were statistically processed with SPSS Statistics 17.0 and Statistica 6.0 software packages.

$H I V$ prevalence among commercial sex workers was rather different on the examined territories. It amounted to $42.6 \%$ and $35.0 \%$ in cities B. and $K$. and it was 2.3 and 1.9 times higher accordingly than in city P. It was detected that there were several factors making for HIV infection spread among CSW; they were high morbidity with HIV on a given territory; an early start of sexual life; disregard of contraception; drug abuse; medical services and prevention programs being hardly available to CSW. A high probability that CSW would get infected with HIV was determined for people who didn't use condoms, took drugs intravenously, and were not epidemiologically alerted to HIV infection.

Key words: HIV-infection, prevalence, contagion, susceptible groups, commercial sex-workers, ecological epidemiological study, case-control study.

Prevention from HIV-infection/AIDS is the moment. The most susceptible populaa priority issue for pubic healthcare due to tion groups include people who take drugs pandemic HIV spread, gravest socioeco- via injections, men who have homosexual nomic consequences of the pandemic and contacts, and commercial sex workers absence of any specific prevention tools at $(\mathrm{CSW})^{1}$ as well.

(c) Golodnova S.O., Fel'dblyum I.V., Yurkova L.V., Sarmometov E.V., Nikolenko V.V., 2020

Svetlana O. Golodnova - Candidate of Medical Sciences, Assistant at the Epidemiology and Hygiene Department (e-mail: epidperm@mail.ru; tel.: +7 (342) 218-16-68; ORCID: https://orcid.org/0000-0001-9792-7491).

Irina V. Fel'dblyum - Doctor of Medical Sciences, Professor, Head of the Epidemiology and Hygiene Department (e-mail: epidperm@mail.ru; tel.: +7 (342) 218-16-68; ORCID: https://orcid.org/0000-0003-4398-5703).

Larisa V. Yurkova - Deputy Minister, Head of the Department for Drug Elimination Activities Coordination (e-mail: lviurkova@mtb.permkrai.ru; tel.: +7 (342) 217-71-56; ORCID: https://orcid.org/0000-0001-8031-9676).

Evgenii V. Sarmometov - Candidate of Medical Sciences, The Chief Physician (e-mail: aidscentr@mail.ru; tel.: +7 (342) 285-03-56; ORCID: https://orcid.org/0000-0003-0134-1686).

Vera V. Nikolenko - Doctor of Medical Sciences, Professor at the Communicable Diseases Department (e-mail: vvn73@yandex.ru; tel.: +7 (342) 236-45-66; ORCID: https://orcid.org/0000-0002-9505-1569).

${ }^{1}$ SR 3.1.5.2826-10. HIV-infection prevention: Sanitary-epidemiologic rules issued on January 11, 2011 No. 1. KODEKS: an electronic fund for legal and reference documentation. Available at: http://docs.cntd.ru/document/902256311 (03.08.2020) (in Russian). 
HIV-infection burden among CSW was analyzed in 50 countries with low and middle income; the analysis revealed that overall HIV-infection prevalence amounted to $11.8 \%$ in these population groups and it was significantly (13.5 times) higher than among overall female population in those countries $[1,2]$. The parameter was different in different regions, varying from $0.2-1.8 \%$ in the Middle East and North Africa up to $36.9 \%$ in African countries located to the south from Sahara [3-7]. In Southern Asia countries and in Latin America HIV-infection prevalence among CSW doesn't differ authentically from the same parameter among overall population and amounts to $5.1 \%$ and $4.4 \%$ accordingly. $\mathrm{HIV}$-infection prevalence is higher in Eastern Europe, $10.9 \%$, and the USA, $15.0 \%$; the parameter is $1.8 \%$ in high-income European countries $[5,8]$.

In Russia HIV-infection prevalence among CSW remains unknown due to this target population group being almost unavailable for any systemic research. There are results obtained via some sporadic studies; according to them, HIV-infection prevalence among CSW varies from $2.3 \%$ to $20.3 \%$ and is $2-12$ times higher than among overall country population [9-15].

Given all the above stated, our research goal was to examine HIV-infection prevalence among CSW and to determine risk factors that caused their contagion with the infection.

Data and methods. HIV-infection prevalence among CSW and risk factors that make for the infection spread in this population group were examined via an epidemiologic analytical and ecological study; 154 CSW from three urban settlements located in Perm region took part in it. Two settlements, B. $(n=54)$ and K. $(n=40)$ were characterized with high morbidity with HIV-infection that was 1.9 times and 1.5 times higher accordingly than in the region in general. The $3^{\text {rd }}$ settlement, P. $(n=60)$ was included as a reference territory since situation there regarding HIVinfection was relatively well. All the examined groups were similar in terms of sex and age; average respondents' age amounted to 32.7, 32.9 and 30.8 in settlements B., K., and P. accordingly $(p=0.000)$.

Risk factors that made for CSW getting infected with HIV were examined via «case control» epidemiologic observation analytical study. «Case» group included $46 \mathrm{CSW}$ who were infected with HIV; reference group was made up of $108 \mathrm{CSW}$ who were not infected with it.

Sociological questioning was performed via formalized interviews. They were performed anonymously with a questionnaire specifically designed by the «Open Health Institute» (a structured questionnaire). It was created taking into account recommendations by the World Health Organization and Russian regulatory-methodical documents on performing biological-behavioral studies among population groups who ran elevated risks of getting infected with HIV. The questionnaire included the following sections: record data (sex, age, and education); sexual contacts history (age at which the $1^{\text {st }}$ sexual contact took place, number of sexual partners, and use of condoms); psychoactive drugs intake; access to public healthcare services and HIV-infection preventive programs.

All the obtained data were statistically processed with SPSS Statistics 17.0 and Statistica 6.0 software packages. We applied Kolmogorov-Smirnov test to assess whether parameters were distributed normally. In case quantitative parameters distribution was normal, data were processed with Student's t-test $(t)$ for two independent samplings and results were given as a simple mean $(M) \pm$ standard error $(m)$; in case quantitative parameters distribution was not normal, data were processed with Mann-Whitney test for two independent variables and results were given as median with lower and upper quartiles (Me [LQ; UQ]). To determine statistical significance of discrepancies between results obtained for quantitative parameters, we applied Fischer's angular transformation test $(\varphi)$. Critical significance was taken as $0.05(p \leq 0.05)$ in this research. 
Results and discussion. We assessed $\mathrm{HIV}$-infection prevalence among CSW; the assessment revealed that $42.6 \pm 6.7 \%$ respondents from B. were HIV-infected; $35.0 \pm 7.5 \%$, from K. $(p=0.15)$. HIV-infection prevalence amounted to $18.3 \pm 3.6 \%$ in $\mathrm{P}$. and it was 2.3 and 1.9 times lower than in $B$. and $K$. ( $p=0.000$ and $p=0.000$ accordingly). HIVinfection prevalence among CSW correlated with HIV-infection epidemic intensity on the examined territories $(r=0.78)$. Thus, average long-term (2015-2019) morbidity with HIVinfection in $\mathrm{P}$. where HIV-infection prevalence among CSW was the lowest amounted to $126.1 \pm 3.5$ cases per 100 thousand people against $193.2 \pm 11.8$ and $185.9 \pm 18.9$ in $\mathrm{B}$. and K. accordingly.

Comparative assessment of results obtained via questioning performed among CSW living on the examined territories and aimed at determining their sexual behavior traits revealed certain discrepancies (Table 1).

Thus, there were no authentic discrepancies in the age at which respondents in the settlements B. and K. had their first sexual contact as it was 15.6 and 15.7 accordingly. CSW from the settlement P. started their sexual life significantly later, at $16.3 \quad(p=0.044$ and $p=0.05)$. The lowest sexual activity was detected in B. where CSW had up to $65[40 ; 120]$ sexual partners annually; this number was 5 times higher for CSW from K. and P., $325[100 ; 662.5]$ and $400[106 ; 685]$ accordingly. And only $64.8 \pm 6.5 \% \mathrm{CSW}$ from B. and $62.5 \pm 7.7 \% \mathrm{CSW}$ from $\mathrm{K}$. used condoms whereas all the CSW from P. did it $(p=0.000)$. Each second respondent in B. $(50.5 \pm 6.8 \%)$ stated there were people infected with HIV among her sexual partners over the last year; the parameter was lower in $\mathrm{K}$. and $\mathrm{P}$. and amounted to $25 \pm 6.8 \%$ and $16.7 \pm 4.8 \%$ accordingly $(p=0.000)$. We should note that $56 \pm 6.8 \% \mathrm{CSW}$ from B. who had sexual contacts with HIV-infected people didn't use condoms. We established that more than half CSW from B. took drugs via injections $(50.7 \pm 6.8 \%)$; only $27.5 \pm 7.1 \%$ respondents from $\mathrm{K}$. admitted intravenous drug intake, and as for CSW from P., they took drugs via injections much less frequently $(p=0.000$ and $p=0.05$ accordingly).

We assessed whether CSW had easy access to medical aid and prevention programs; our assessment revealed that 9 out of $10 \mathrm{CSW}$ from B., K., and P. had had HIV-infection tests $(95.0 \pm 2.9 \% ; \quad 90 \pm 4.7 \%$, and $93.3 \pm 3.2 \%$

Table 1

Risk factors of HIV spread among commercial sex workers on unfavorable territories (settlements B. and K.) and a favorable (settlement P.) one regarding HIV-infection in Perm region $(\%)$

\begin{tabular}{|c|l|c|c|c|}
\hline \multirow{2}{*}{ No. } & \multicolumn{1}{|c|}{ Risk factors } & \multicolumn{3}{|c|}{ Settlement } \\
\cline { 3 - 5 } & \multicolumn{1}{|c|}{$\begin{array}{l}\text { B. } \\
\text { place }\end{array}$} & 15.6 & 15.7 & $16.3^{*}$ \\
\hline 2. & Number of sexual partners per year & $65[40 ; 120]$ & $400[106 ; 685]$ & $325[100 ; 662.5]$ \\
\hline 3. & Use of condoms & $64.8 \pm 6.5 \%$ & $62.5 \pm 7.7 \%$ & $100 \%{ }^{*}$ \\
\hline 4. & HIV-infected people among sexual partners & $50.5 \pm 6.8 \%$ & $25 \pm 6.8 \%$ & $16.7 \pm 4.8 \%$ \\
\hline 5. & Intravenous drugs intake & $50.7 \pm 6.8 \%$ & $27.5 \pm 7.1$ & $16.9 \pm 4.8 \%{ }^{*}$ \\
\hline 6. & HIV-testing during the last year & $45.3 \pm 6.8 \%$ & $52.6 \pm 7.9 \%$ & $80.4 \pm 5.1 \%^{*}$ \\
\hline 7. & Pre-testing consultation & $28.3 \pm 6.1 \%$ & $39.5 \pm 7.7 \%$ & $55.4 \pm 6.4 \%{ }^{*}$ \\
\hline 8. & Consultations after testing & $32.1 \pm 6.4 \%$ & $34.2 \pm 7.5 \%$ & $50.0 \pm 6.5 \%{ }^{*}$ \\
\hline 9. & $\begin{array}{l}\text { Participation in programs aimed at complex } \\
\text { HIV prevention }\end{array}$ & $7.4 \pm 3.5 \%$ & $30.9 \pm 7.3 \%$ & $73.3 \pm 5.7 \%{ }^{*}$ \\
\hline
\end{tabular}

Note: ${ }^{*}$ means validity at $p \leq 0.05$. 
accordingly). Approximately half CSW from B. and $\mathrm{K}$. had got their HIV tests over the last year ( $45.3 \pm 6.8 \%$ and $52.6 \pm 7.9 \%$ accordingly); the parameter was authentically higher in P. and amounted to $80.4 \pm 5.1 \% \quad(p=0.004$ and $p=0.000$ accordingly). But still, pre- and aftertests consulting was provided for rather few people from this social group. Thus, in B. and $\mathrm{K}$. only one third of respondents got any consultation before testing $(28.3 \pm 6.1 \%$ and $39.5 \pm 7.7 \%$ accordingly) and after testing $(32.1 \pm 6.4 \%$ and $34.2 \pm 7.5 \%$ accordingly); the parameter was 1.2-2.0 times higher in P. and amounted to $55.4 \pm 6.4 \% \quad(p=0.004$; $p=0.05$ accordingly $)$ and $50.0 \pm 6.5 \%(p=0.05$; $p=0.05)$ accordingly. Pre- and after-tests consultations are obviously a significant prophylactic activity that allows preventing HIV-infection spread; in spite of this fact each second tested respondent was not provided with necessary information on the infection burden and basic ways to prevent it.

Only 4 CSW from B. were aware that there was a complex HIV-infection prevention program for them $(7.4 \pm 3.5 \%)$ and even they had never participated in it. Only each third respondent from $\mathrm{K}$. knew about the existing prevention programs $(30.9 \pm 7.3 \%)(p=0.000)$ and took part in them. More than half CSW from P. $(73.3 \pm 5.7 \%)$ were not only well aware of such programs but also took active part in them.

Our research results indicate that there are several risk factors that make for HIVinfection spread among CSW. They are early

age at which the $1^{\text {st }}$ sexual contact took place; negligent attitude towards using condoms; intravenous drugs intake; HIV-testing being rather rare, rarer than once a year; rather few CSW provided with pre- and after-tests consulting and participating in the existing complex programs aimed at HIV-infection prevention.

Risk factors that can cause HIV-infection spread among CSR were estimated via «case control» study; the estimation revealed that each sixth HIV-infected CSW took drugs via injections $(60.9 \pm 7.2 \%)$ against $13.9 \pm 3.3 \%$ in «control» group (Table 2). CSW who took drugs intravenously ran 9.6 times higher risks to get infected with HIV than CSW who didn't take drugs (OR 9.6; [95 \% CI: 4.3-21.6]). Intravenous drug intake is obviously a significant factor that makes for CSW getting infected with HIV.

Meth cathinones, or synthetic drugs (usually called «bath salts»), are at present the most widely used drugs in Perm region. They belong to psychoactive drugs and can change a person's sexual behavior due to specific effects produced on human mind; it results in growing number of promiscuous and unsafe sexual contacts and such contacts, in their turn, lead to HIV-infection spread via sex becoming more significant among CSW [10, 16].

We established that use of condoms by CSW was a protection factor that led to lower risks of getting infected with HIV (OR 0.14; [95 \% CI: 0.06-0.31]). These results are well

Table 2

Frequency of behavioral risk factors among HIV-infected («case») and not infected («control») commercial sex workers

\begin{tabular}{|c|l|c|c|c|c|c|}
\hline \multirow{2}{*}{ No. } & \multicolumn{1}{|c|}{ Risk factor } & \multicolumn{2}{|c|}{ «case» $(n=46)$} & \multicolumn{2}{|c|}{ «control» $(n=108)$} & \multirow{2}{*}{$p$} \\
\cline { 3 - 6 } & & abs. & $\%$ & abs. & $\%$ & \multirow{2}{*}{$p=0.000$} \\
\hline 1. & Intravenous drug intake & 28 & 60.9 & 15 & 13.9 & $p=0.000$ \\
\hline 2. & Use of condoms & 24 & 52.2 & 96 & 88.9 & $p=0.4$ \\
\hline 3 & $\begin{array}{l}\text { Awareness about basic ways and factors } \\
\text { that make for HIV-infection spread }\end{array}$ & 37 & 80.4 & 39 & 36.1 & $p=0.000$ \\
\hline 4 & HIV-infection testing over the last year & 37 & 80.4 & 54 & 50 & $p=0.000$ \\
\hline 5. & Pre- and after-tests consultations & 26 & 56.5 & 35 & 32.4 & $p=0.005$ \\
\hline
\end{tabular}


in line with data obtained via foreign research works according to which use of condoms results in at least $80 \%$ lower risk of getting infected with HIV [17-20].

We assessed awareness among CSW about how they could get infected with HIV and revealed that $\mathrm{HIV}$-infected CSW were quite well aware about ways and factors that made for HIV-spread; CSW who were not infected were not so well aware (2.2 times lower number, $p=0.000)$. Obviously, CSW become interested in the infections and ways to get infected with it only after the contagion. Low awareness among CSW who are not infected and absence of any stimuli to have safe sexual contacts indicate that this population group still runs rather high risks of getting infected with HIV.

Our sociological questioning revealed that CSW with HIV-infection got pre-and aftertests consultations 1.6-1.7 times more frequently that CSW who were not infected $(p=0.000)$; it indicates that CSW who are not infected are also not alerted regarding the infection and pre-and after-tests consulting has rather low preventive influence on them.
Given all the above stated, we can conclude that probability of getting infected with HIV is higher among those CSW who do not use condoms, take drugs intravenously, and are not properly alerted regarding HIV-infection.

\section{Conclusions.}

1. Factors that make for HIV-infection spread among CSW are high morbidity with HIB-infection on a given territory; early age at which the $1^{\text {st }}$ sexual contact took place; negligent attitude towards using condoms; intravenous drugs intake; CSW having limited access to medical aid and prevention programs.

2. Unsafe sex, intravenous drugs intake, low awareness about risks of infection result in significant increase in probability that CSW may get infected with HIV; commercial sex workers themselves are a real threat for their customers when it comes down on HIV-infection.

Funding. The research was not granted any sponsor support.

Conflict of interests. The authors declare there is no any conflict of interests.

\section{References}

1. Baral S., Beyrer C., Muessig K., Poteat T., Wirtz A.L., Decker M.R., Sherman S.G., Kerrigan D. Burden of HIV among female sex workers in low-income and middle-income countries: a systematic review and meta-analysis. The Lancet Infect. Dis., 2012, vol. 12, no. 7, pp. 538-549. DOI: $10.1016 / \mathrm{S} 1473-3099(12) 70066-\mathrm{X}$

2. Shannon K., Strathdee S.A., Goldenberg S.M., Duff P., Mwangi P., Rusakova M., RezaPaul S., Lau J. [et al.]. Global epidemiology of HIV among female sex workers: influence of structural determinants. The Lancet, 2015, vol. 385, no. 9962, pp. 55-71. DOI:10.1016/S01406736(14)60931-4

3. Shannon K., Crago A.L., Baral S.D., Bekker L.G., Kerrigan D., Decker M.R., Poteat T., Wirtz A.L. [et al.]. The global response and unmet actions for HIV and sex workers. The Lancet, 2018, vol. 392, no. 10148, pp. 698-710. DOI: 10.1016/S0140-6736(18)31439-9

4. Borquez A., Cori A., Pufall E.L., Kasule J., Slaymaker E., Price A., Elmes J., Zaba B. [et al.]. The Incidence Patterns Model to Estimate the Distribution of New HIV Infections in SubSaharan Africa: Development and Validation of a Mathematical Model. PLoS Medicine, 2016, vol. 13, no. 9, pp. 1-31. DOI: 10.1371/journal.pmed.1002121

5. Beyrer C., Crago A.L., Bekker L.G., Butler J., Shannon K., Kerrigan D., Decker M.R., Baral S.D. [et al.]. An action agenda for HIV and sex workers. The Lancet, 2015, vol. 385, no. 9964, pp. 287-301. DOI: 10.1016/S0140-6736(14)60933-8

6. The Global HIV Epidemics among Sex Workers. The World Bank, 2013. Available at: https://www.worldbank.org/content/dam/Worldbank/document/GlobalHIVEpidemicsAmongSexWor kers.pdf (07.01.2020). 
7. Chemaitelly H., Weiss H., Calvert C., Harfouche M., Abu-Raddad L. HIV epidemiology among female sex workers and their clients in the Middle East and North Africa: systematic review, meta-analyses, and meta-regressions. BMC Medicine, 2019, vol. 17, no. 119, pp. 1-30. DOI: 10.1186/s12916-019-1349-y

8. Bautista C.T., Sanchez J.L., Montano S.M., Laguna-Torres A., Suarez L., Sanchez J., Campos P., Gallardo C. [et al.]. Seroprevalence of and risk factors for HIV-1 infection among female commercial sex workers in South America. Sexually Transmitted Infections, 2006, vol. 82, no. 4, pp. 311-316. DOI: 10.1136/sti.2005.018234

9. Sisin E.I., Golubkova A.A., Alimov A.V., Evseeva V.I., Koneva N.D., Gusev A.G., Lelenkova E.V., Piterskii M.V., Chebin A.S. Prevalence of HIV infection among sex workers and features of their risky behavior. Meditsinskii alfavit, 2020, no. 18, pp. 20-22 (in Russian).

10. Plavinskii S.L., Ladnaya N.N., Barinova A.N., Zaitseva E.E. Epidemiologicheskii nadzor II pokoleniya za VICh-infektsiei. Rasprostranennost' VICh-infektsii i riskovannogo povedeniya sredi uyazvimykh grupp naseleniya v 7 regionakh Rossiiskoi Federatsii, rezul'taty bio-povedencheskogo issledovaniya, $2017 \mathrm{~g}$. [The second-generation epidemiologic surveillance over HIV-infection. HIVinfection and risky behavior prevalence among susceptible population groups in 7 RF regions: results obtained via biological behavioral study]. Moscow, Otkrytyi institut zdorov'ya Publ., 2018, 140 p. (in Russian).

11. Vinogradova T.N., Sizova T.D., Bobreshova A.S., Piskarev I.G., Maslova I.A. A study of HIV prevalence with express saliva tests among female commercial sex providers. VICh-infektsiya $i$ immunosupressii, 2013, vol. 5, no. 2, pp. 112-116 (in Russian).

12. Kasymova M.K., Bobokhodzhaeva M.O. Sexually transmitted infections, and HIV, morbidity of commercial sex workers. Vestnik poslediplomnogo obrazovaniya $v$ sfere zdravookhraneniya, 2016, no. 1, pp. 17-22 (in Russian).

13. Taisheva L.A., Minullin I.K., Khamitova R.Ya., Vafina G.G. Epidemiological environment in the field of STD in the Republic of Tatarstan in 1996-2005. Vestnik dermatologii $i$ venerologii, 2008, no. 3, pp. 13-16 (in Russian).

14. Plavinskii S.L., Bobrik A.V., Barinova A.N., Novozhilov A.V., Eroshina K.M. Effectiveness of the harm reduction programs for the HIV prevention in Russian Federation. Rossiiskii semeinyi vrach, 2009, no. 5, pp. 20-24 (in Russian).

15. Prokhorova O.G., Fedotova T.T., Samokhvalova E.V., Zakharova E.A., Bizyaev V.V. Comparison of sociological research data obtained from high HIV infection risk groups in Sverdlovsk oblast. Zdorov'e naseleniya i sreda obitaniya, 2009, no. 7, pp. 12-15 (in Russian).

16. Pozdnyakova M.E. Risky sexual behavior as a factor of HIV infection spread in Russia. Part 1. Sotsiologicheskaya nauka i sotsial'naya praktika, 2018, vol. 6, no. 3 (23), pp. 99-113 (in Russian).

17. Weller S., Davis-Beaty K. Condom effectiveness in reducing heterosexual HIV transmission. Cochrane Database of Systematic Reviews, 2002, no. 1, pp. CD003255. DOI: 10.1002/14651858.CD003255

18. Holmes K., Levine R., Weaver M. Effectiveness of condoms in preventing sexually transmitted infections. Bulletin of the World Health Organization, 2004, vol. 82, no. 6, pp. 454-461.

19. Position statement on condoms and HIV prevention. Geneva, Joint United Nations Programme on HIV/AIDS Publ., 2009, 2 p.

20. Use and procurement of additional lubricants for male and female condoms: advisory note. Geneva, World Health Organization Publ., 2012, 8 p.

Golodnova S.O., Fel'dblyum I.V., Yurkova L.V., Sarmometov E.V., Nikolenko V.V. Factors that cause contagion and spread of HIV among people from social risk groups. Health Risk Analysis, 2020, no. 4, pp. 130-135. DOI: 10.21668/health.risk/2020.4.15.eng

Received: 18.08 .2020

Accepted: 05.11.2020

Published: 30.12.2020 